\title{
Sustainability Assessment of Chemical Processes: Evaluation of Three Synthesis Routes of DMC
}

\author{
Paula Saavalainen, ${ }^{1}$ Satish Kabra, ${ }^{2}$ Esa Turpeinen, ${ }^{1}$ Kati Oravisjärvi, ${ }^{1}$ \\ Ganapati D. Yadav, ${ }^{2}$ Riitta L. Keiski, ${ }^{1}$ and Eva Pongrácz ${ }^{3}$ \\ ${ }^{1}$ Environmental and Chemical Engineering, Faculty of Technology, University of Oulu, P.O. Box 4300, 90014 Oulu, Finland \\ ${ }^{2}$ Department of Chemical Engineering, Institute of Chemical Technology (ICT), Matunga, Mumbai 400019, India \\ ${ }^{3}$ Thule Institute, NorTech Oulu, University of Oulu, P.O. Box 7300, 90014 Oulu, Finland \\ Correspondence should be addressed to Paula Saavalainen; paula.saavalainen@oulu.fi
}

Received 11 December 2014; Accepted 27 January 2015

Academic Editor: Danielle Ballivet-Tkatchenko

Copyright (C) 2015 Paula Saavalainen et al. This is an open access article distributed under the Creative Commons Attribution License, which permits unrestricted use, distribution, and reproduction in any medium, provided the original work is properly cited.

\begin{abstract}
This paper suggested multicriteria based evaluation tool to assess the sustainability of three different reaction routes to dimethyl carbonate: direct synthesis from carbon dioxide and methanol, transesterification of methanol and propylene carbonate, and oxidative carbonylation of methanol. The first two routes are $\mathrm{CO}_{2}$-based and in a research and development phase, whereas the last one is a commercial process. The set of environmental, social, and economic indicators selected were renewability of feedstock, energy intensity, waste generation, $\mathrm{CO}_{2}$ balance, yield, feedstock price, process costs, health and safety issues of feedstock, process conditions, and innovation potential. The performance in these indicators was evaluated with the normalized scores from 0 to $+1 ; 0$ for detrimental and 1 for favorable impacts. The assessment showed that the transesterification route had the best potential toward sustainability, although there is still much development needed to improve yield. Further, the assessment gave clear understanding of the main benefits of each reaction route, as well as the major challenges to sustainability, which can further aid in orienting development efforts to key issues that need improvement. Finally, it was concluded that a multicriteria analysis such as the one presented in this paper was a viable method to be used in the process design stage.
\end{abstract}

\section{Introduction}

In the last decades, sustainable development has become the cornerstone of environmental policy and a leading principle for resource management. The widely used definition of sustainable development is that of the United Nations' Brundtland Commission [1]: "Development that meets the needs of the present without compromising the ability of future generations to meet their own needs." In corporate terms, sustainability can be summarized as the "triple bottom line" (TBL) success [2], which implies that firms have to maintain and grow their economic, social, and environmental capital base, while actively contributing to sustainability in the political domain $[3,4]$.

One of the key challenges of sustainable development is that it demands new and innovative choices and ways of thinking. Innovations in technology are challenging organizations to make new choices in their operations, products, and activities that impact the earth and people as well as economics [5]. There is, however, no standard method for measuring the triple bottom line success of technological innovations at the design phase and the principles to achieve sustainability by themselves are insufficient to create the right framework for design towards sustainability [6]. It would be useful to have a screening tool to assess how a new product or process under development would perform in terms of sustainability, or compared with a commercial process. Although there are various international efforts to measure sustainability, only a few of them have an integral approach taking into account environmental, economic, and social aspects. In most cases, the focus is on one of the three aspects [7]. For example, Life Cycle Assessment (LCA) is used to evaluate the environmental performance of products, 
but it concentrates on environmental impacts only [8]. As well, environmental impact assessment (EIA), a procedural tool for the design phase, only evaluates the environmental implications of decisions [9].

In order to fully evaluate the sustainability of new process routes, there is a need for a comprehensive evaluation of the environmental, economic, and social impacts of these new routes at an early process design stage. The paper suggests using multicriteria assessment for sustainability assessment and demonstrates its use in assessing a novel carbon dioxidebased reaction route to dimethyl carbonate (DMC).

\section{Sustainability Assessment Methodologies}

There are a number of sustainability assessment methodologies evaluating the performance of industrial facilities. The World Business Council for Sustainable Development [10], the Global Reporting Initiative [5], and development of standards [11] are key drivers for adopting sustainability management in industries.

The most extensive work in terms of sustainability assessment has been done by the Global Reporting Initiative (GRI). GRI is a nongovernmental organization that aims at driving sustainability and has developed an environmental, social, and governance (ESG) reporting framework to be used worldwide. GRI version 4 on Sustainability Reporting Guidelines defines the principles and indicators that organizations can use to measure and report their economic, environmental, and social performance. Many companies use these indicators while publishing their annual or environmental reports. GRI is committed to continuously improve and increase the use of the guidelines which are available to the public [5].

The American Institute of Chemical Engineers (AIChE) has defined the AIChE Sustainability Index (SI) to measure the sustainability performance of representative companies in chemical industry [12]. The AIChE SI uses publicly available data on the companies' strategic commitment, sustainability innovation, environmental performance, safety performance, product stewardship, social responsibility, and value chain management to measure their sustainability performance. Metrics to measure the "greenness" of the companies' chemistry have been developed by the American Institute of Chemical Engineers' Center for Waste Reduction Technologies (AIChE/CWRT) assessing material intensity, energy intensity, water consumption, toxic release, and pollutant effects. The metrics developed are simple, understandable, easy to reproduce, and comparable [13]. They take into notice also the social aspects of sustainability by considering the health effects the chemicals used/produced have. However, they are developed for companies and are adjusted for existing process improvements rather than for a new process design.

Similarly, the Institution of Chemical Engineers (IChemE) has developed a set of metrics to enable process industry companies to measure and report progress along the path of sustainable development [14]. The Sustainable Development Progress Metrics are intended to help companies to set targets and develop internal standards and to monitor their progress in time [15]. The IChemE metrics are divided into environmental, economic, and social indicators. The environmental indicators are concentrating on resource use by considering how much energy, material, and water are consumed and land is used. Also atmospheric, aquatic impacts, and impacts on land caused by emissions, effluents, and waste are taken into notice. The economic indicators are concentrating on the profit gained, value added and taxes paid, and investments made by the company. The social indicators are considering the employment situation, health and safety at work, and also impacts to society. Not all the metrics proposed are valid in every case and it is up to the companies to decide which of the metrics are relevant for them. Key indicators have to be chosen from each of the aspects of sustainability to give a balanced view of the sustainability performance [15]. Whilst the IChemE metrics account for all three aspects of sustainability, they are meant as a sustainability management tool for companies, aiming at enhancing their sustainability performance, and are not suitable for assessing processes under development.

In terms of sustainability guidance for chemicals and chemical process design, Green Chemistry was developed to reduce or eliminate negative environmental impacts $[16,17]$. The 12 Principles of Green Chemistry have been a cornerstone of environmentally conscious chemical process design since the late 1990s. Green Chemistry had been suggested to be used as a pollution prevention tool as it applies innovative scientific solutions to real-world environmental situations [18]. However, the assessment range of Green Chemistry does not cover the full depth of sustainability. As it was its original purpose, its emphasis is on reducing the toxicity of chemical products and driving inherently safer chemistry.

Protection of human health and the environment from chemicals and associated risks is also the goal of the European REACH (The Registration, Evaluation, Authorization and Restriction of Chemicals) regulation, which came into force in 2007. It renewed and upgraded the previous chemicals regulatory framework of the European Union (EU) [19], in order to ensure that there is free circulation of substances on the internal market and to enhance competitiveness and innovation. REACH confirms that industries are responsible for both assessing and managing the risks associated with chemicals, giving suitable safety information of chemicals to users, and promoting alternative testing methods [20]. About 143000 chemicals marketed in the EU were preregistered by the December 1, 2008, deadline in REACH. The registration document of chemicals under REACH includes general information, safety data sheets (SDS), chemical safety report (CSR), and chemical safety assessment (CSA). Testing for health hazards under REACH includes acute toxicity, skin corrosion and irritation, serious eye damage and irritation, skin or respiratory sensitizer effect, mutagenic or carcinogenic impacts, toxicity for reproduction, specific target organ toxin in single exposure, specific target organ toxin in repeated exposure, and aspiration hazard [21, 22].

Table 1 summarizes some of the main evaluation guidelines or indicators used in the mentioned assessment processes. All methods outlined in Table 1 take into notice some 
TABLE 1: Main principles/evaluation guidelines of reviewed assessment methods [5, 12-16].

\begin{tabular}{|c|c|c|c|c|}
\hline & GRI & AIChE & IChemE & Green Chemistry \\
\hline $\begin{array}{l}\text { Environmental } \\
\text { performance }\end{array}$ & $\begin{array}{l}\text { Materials } \\
\text { Energy } \\
\text { Water } \\
\text { Biodiversity } \\
\text { Emissions } \\
\text { Effluents and waste } \\
\text { Products and services } \\
\text { Compliance } \\
\text { Transport } \\
\text { Suppliers }\end{array}$ & $\begin{array}{l}\text { (i) Resource use } \\
\text { (a) Energy } \\
\text { (b) Materials } \\
\text { (c) Renewables } \\
\text { (d) Water } \\
\text { GHG emissions } \\
\text { Waste, wastewater } \\
\text { Compliance management } \\
\text { Value chain management }\end{array}$ & $\begin{array}{l}\text { Resource usage } \\
\text { (i) Energy } \\
\text { (ii) Material } \\
\text { (iii) Water } \\
\text { (iv) Land } \\
\text { Emissions, effluents, } \\
\text { and waste }\end{array}$ & $\begin{array}{l}\text { Prevent waste } \\
\text { Use renewable feedstock } \\
\text { Avoid chemical derivatives } \\
\text { Catalysts } \\
\text { Product degradability }\end{array}$ \\
\hline $\begin{array}{l}\text { Economic } \\
\text { performance }\end{array}$ & $\begin{array}{l}\text { Economic performance } \\
\text { Market presence } \\
\text { Procurement practices }\end{array}$ & $\begin{array}{l}\text { (i) Sustainability } \\
\text { innovation } \\
\text { (ii) Strategic commitment } \\
\text { to sustainability }\end{array}$ & $\begin{array}{l}\text { Profit, value, tax } \\
\text { (i) Investments }\end{array}$ & $\begin{array}{l}\text { Maximise atom economy } \\
\text { Increase energy efficiency }\end{array}$ \\
\hline $\begin{array}{l}\text { Social } \\
\text { performance }\end{array}$ & $\begin{array}{l}\text { Labor practices } \\
\text { (i) Employment } \\
\text { (ii) Health and safety } \\
\text { (iii) Innovation and } \\
\text { knowledge potential } \\
\text { (iv) Diversity and equality } \\
\text { society } \\
\text { (i) Acceptability and social } \\
\text { dialogue } \\
\text { Human rights }\end{array}$ & $\begin{array}{l}\text { Social responsibility } \\
\text { (i) Stakeholder partnership } \\
\text { (ii) Social investment } \\
\text { (iii) Image in the } \\
\text { community } \\
\text { Product stewardship } \\
\text { (i) assurance system } \\
\text { (ii) risk communication } \\
\text { (iii) legal proceedings }\end{array}$ & $\begin{array}{l}\text { Workplace } \\
\text { (i) Employment } \\
\text { (ii) Health and safety } \\
\text { society }\end{array}$ & $\begin{array}{l}\text { Less hazardous chemical } \\
\text { syntheses } \\
\text { Safer chemicals, products } \\
\text { solvents, and reactions } \\
\text { Accident prevention and } \\
\text { real time analysis }\end{array}$ \\
\hline
\end{tabular}

key aspects of sustainability and clearly intend to evaluate triple bottom line success. Indicators that are possible to assess in the design phase and would give a good signal of sustainability performance are bolded. In terms of sustainability assessment of chemical processes in the design phase, Green Chemistry is the most thorough; however, should it be used to assess sustainability, it is recommended to extend it with social and economic indicators of GRI, AIChE, and IChemE to give a comprehensive measure of sustainability.

Following the recommendation of IChemE, we selected key indicators from each of the aspects of sustainability to give a balanced view of the sustainability performance. The suggested indicators are as follows:

(i) environmental indicators:
(a) feedstock renewability,
(b) energy intensity,
(c) waste generation,
(d) $\mathrm{CO}_{2}$ balance,

(ii) economic indicators:
(a) yield,
(b) feedstock price,
(c) process costs,

(iii) social indicators:
(a) process conditions,
(b) chemicals safety,
(c) innovation potential.

TABLE 2: The assessed reaction routes for DMC production.

Route A: direct synthesis from carbon dioxide and methanol

$\mathrm{CO}_{2}+2 \mathrm{CH}_{3} \mathrm{OH} \rightarrow\left(\mathrm{CH}_{3} \mathrm{O}\right)_{2} \mathrm{CO}+\mathrm{H}_{2} \mathrm{O}$

Route $\mathrm{B}$ : transesterification of methanol and propylene carbonate using ionic liquid (IL) as a catalyst

$\mathrm{C}_{3} \mathrm{H}_{6} \mathrm{O}+\mathrm{CO}_{2} \rightarrow \mathrm{C}_{4} \mathrm{H}_{6} \mathrm{O}_{3}$

$\mathrm{C}_{4} \mathrm{H}_{6} \mathrm{O}_{3}+2 \mathrm{CH}_{3} \mathrm{OH} \rightarrow\left(\mathrm{CH}_{3} \mathrm{O}\right)_{2} \mathrm{CO}+\mathrm{C}_{3} \mathrm{H}_{8} \mathrm{O}_{2}$

Route $\mathrm{C}$ : oxidative carbonylation of methanol (ENiChem)

$2 \mathrm{CH}_{3} \mathrm{OH}+1 / 2 \mathrm{O}_{2}+\mathrm{CO} \rightarrow\left(\mathrm{CH}_{3} \mathrm{O}\right)_{2} \mathrm{CO}+\mathrm{H}_{2} \mathrm{O}$

These indicators were selected as they can be assessed based on reaction routes as well as laboratory scale experiments and thermodynamic simulations. We propose that these 10 indicators are a necessary and sufficient set of meters for screening purposes at the design phase and give a balanced view of chemical process sustainability.

\section{Assessment of DMC Production Routes}

Dimethyl carbonate (DMC, $\left.\left(\mathrm{CH}_{3}\right)_{2} \mathrm{CO}\right)$ is an important chemical intermediate that can be used as a fuel additive and a polar solvent in the chemical industry. The production of DMC has received increasing attention over the least years [23-28]. There are several methods for the synthesis of DMC, such as phosgenation of methanol, oxidative carbonylation of methanol, transesterification method, and esterification of carbon dioxide with methanol [29-31]. In this paper, three reaction routes for DMC synthesis are evaluated. The reaction routes are outlined in Table 2. 


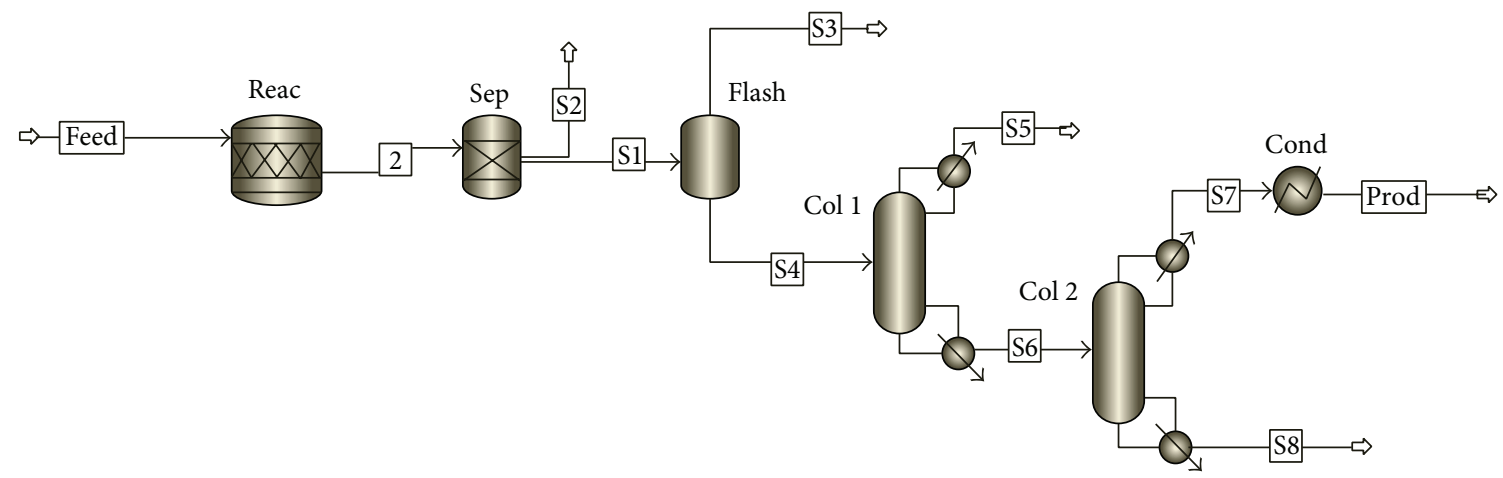

Figure 1: Process flow sheet for Routes A and C.

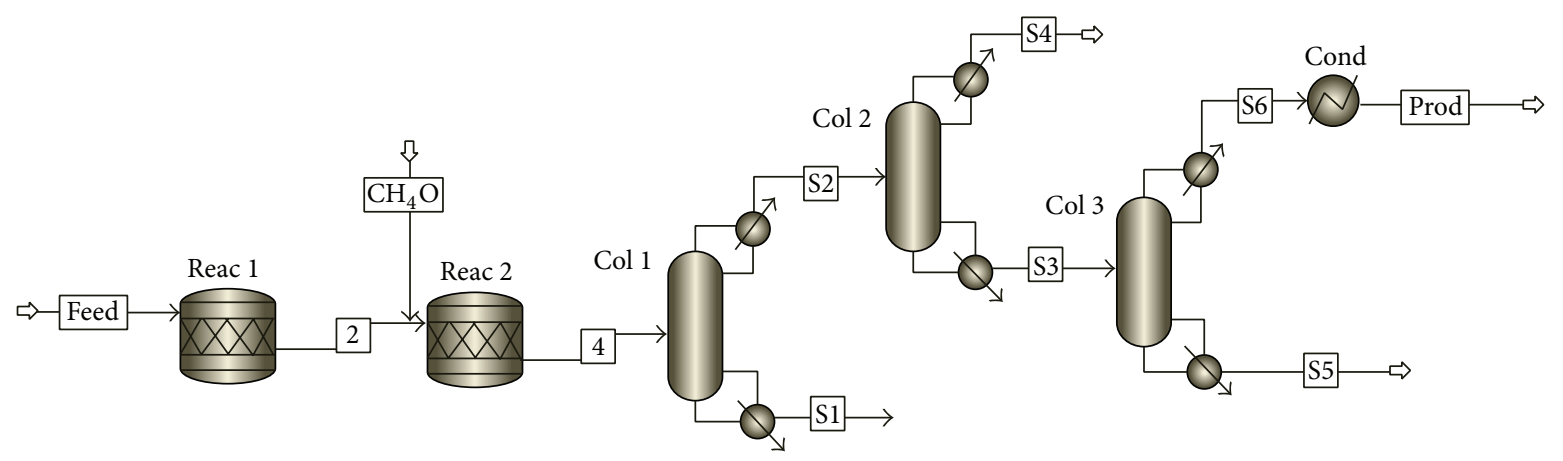

Figure 2: Process flow sheet for Route B.

All three routes provide a safer alternative for the primary synthesis pathway, the "phosgene route" $\mathrm{COCl}_{2}+2 \mathrm{CH}_{3} \mathrm{OH}$ $\rightarrow\left(\mathrm{CH}_{3} \mathrm{O}\right)_{2} \mathrm{CO}+2 \mathrm{HCl}$. The use of phosgene route is phased out from the commercial processes, as phosgene is one of the most acutely toxic substances used in industrial scale. As this route presents inherent hazards and potential environmental problems in handling and waste disposal [23], it is crucial that it is replaced by a more sustainable method.

Route A is currently in academic research phase. This route is particularly attractive for being $\mathrm{CO}_{2}$-based. Generally speaking, carbon dioxide $\left(\mathrm{CO}_{2}\right)$ can be considered as an environmentally friendly and widely available feedstock, available as a waste emission of industrial processes. Chemical utilization of $\mathrm{CO}_{2}$ for DMC manufacture would be a means to turn this waste into a nonwaste, allowing us to view $\mathrm{CO}_{2}$ as a useful resource. It has been reported earlier that $\mathrm{CO}_{2}{ }^{-}$ based synthesis processes are meeting many of the provisions for environmental, economic, and social sustainability [32]. Therefore, much academic research has concentrated on the search for benign by design synthesis involving $\mathrm{CO}_{2}$ as a raw material [33]. The synthesis of carbonic esters is one example [34]. The expectation is that the $\mathrm{CO}_{2}$-based DMC production routes have significant potentials toward sustainable production. However, there are also numerous challenges of $\mathrm{CO}_{2}$ utilization [32]; therefore, long-term research efforts for acquiring the necessary knowledge in its chemical reactivity are needed.

Route $\mathrm{B}$ is also an attractive "carbon-friendly" route, due to using $\mathrm{CO}_{2}$ as a reaction feedstock. However, the complexity of a two-step process, the use of toxic propylene oxide, and the coproduction of propylene glycol make this process demanding. The challenge in both Routes $\mathrm{A}$ and $\mathrm{B}$ is that scale-up of the production would not be economically feasible at the moment.

The commercial route (ENiChem), Route $\mathrm{C}$, is based on the catalytic oxidative carbonylation of methanol. It offers operational and environmental advantages, for example, fewer side products, better atom economy, and safer production comparing to the phosgene route $[23,33]$ but it is not responding to the current demand of DMC.

In terms of "measuring" innovation potential, we performed a literature review using a simple keyword search in Science Direct to evaluate the volume of publications and calculated the percentage of recent publications (2012 or later) of the 50 most relevant publications. Our reasoning is that the volume of publications is indicative of the level of knowledge potential, and the high percentage of recent publications indicates intensified academic interest, which will contribute to the renewal of science and is more likely to drive innovation.

\section{Process Simulations}

Mass and energy balances of process routes were calculated by Aspen Plus simulations. Process flow sheets are presented in Figures 1 and 2. In order to make comparison of processes simple and appropriate the flow sheets were designed as similar as possible. Processes A and C consist of a reactor, gas separation unit, flash separator, and two columns. Process B 
is composed of two reactors and three columns. The reactors used were modeled as stoichiometric reactors based on known fractional conversion of a certain component. Radfrac model was used in separation units. The routes were assumed to be ideal (no mass and heat losses and no pressure drops and ideal component properties). The foundation for the calculation was stoichiometric, based on reaction equation, $1 \mathrm{kmol}$ of each. The process conditions for the inlet stream were as follows: temperature $20^{\circ} \mathrm{C}$ and pressure 1 bar. The outlet stream temperature was set at $20^{\circ} \mathrm{C}$ and pressure at 1 bar. Concentration of DMC after purification was adjusted to 85 vol- $\%$.

Detailed descriptions of the process units and conditions are presented in Tables 3-5.

\section{Assessment Process for Reaction Routes}

The assumptions for all 3 reaction routes used in the assessment are summarized in Table 6 and the simulation results are gathered in Table 7. Process details (reactants, products, solvents, wastes, catalyst, temperature, pressure, conversion, and selectivity) were taken from the articles or/and academic theses [25, 35-39]. In addition, in Table 6 also the data for the literature review was included.

In reaction Route $\mathrm{A}$, fossil fuel based raw materials are used, where it is assumed that methanol is produced with carbon monoxide (CO), $\mathrm{CO}_{2}$, and hydrogen $\left(\mathrm{H}_{2}\right)$. Reaction Route $\mathrm{B}$ uses oil refinery products and $\mathrm{CO}_{2}$ as raw material. In reaction Routes $\mathrm{A}$ and $\mathrm{B}$, commercial catalytic materials are under development. The academic research toward reaction Route A uses calcined hydrotalcite on hexagonal mesoporous silica (CHT-HMS) as a catalyst with an IL promoter. In reaction Route $\mathrm{B}$, ion exchange resin and ionic liquid (IL) are used as catalyst material. Finally, in Route C, commercial copper chloride catalysts are used. Catalytic materials for routes under development should be chosen for the assessment in order to minimize the environmental impact of catalyst materials, that is, enhancement of reaction activity and selectivity and stability of the catalyst, as well as environmentally benign catalytic materials.

In reaction Routes $\mathrm{A}$ and $\mathrm{B}$, optimal reaction conditions such as temperature and pressure are not yet resolved as these routes are still under development; however, they are expected to be rather high and supercritical $\mathrm{CO}_{2}$ is used. Reaction conditions should further be developed so that temperature and pressure are optimized at a lower level to minimize risks and environmental impacts. Reactions in Route $\mathrm{C}$ are using lower pressure, but higher temperature. The environmental benefit of this is to be highlighted, when compared with routes under research.

In reaction Routes $\mathrm{A}$ and $\mathrm{C}$, only water is produced as a by-product. In Route A also small amounts of methylformate are produced. In Route B, toxic propylene glycol is produced. Propylene glycol is valuable from a commercial point of view; however its possible utilization needs to be considered at the design phase.

Atom economy is the best for the methanol-based reaction Routes A and C. However, it needs to be assessed if the atom economy benefit overweighs other impacts of the reactions. Reaction route $\mathrm{C}$ uses $\mathrm{CO}$ as a raw material, the production of which is rather energy demanding. In reaction Routes A and B, the yield is very low because of low conversion of methanol. This highlights the need for research for more efficient catalyst materials.

Prices of feedstock were acquired from chemical suppliers. Total operating costs were calculated by summing prices of feedstock and energy consumption of the process. Energy consumption of the process (MJ) was converted to euros by rate of $0.27 \mathrm{e} / \mathrm{MJ}$ (Eurostat). Capital costs were left out of considerations because all the cases are quite similar, and thus they were assumed to be equal in capital costs.

\section{Sustainability Assessment of DMC Routes}

Sustainability assessments are multicriteria based evaluations, which necessitate the inclusion of a wide variety of data typology with various certainty degrees. In this paper, we use multicriteria assessment (MCA) to perform the evaluation of the three DMC routes. Various multicriteria decision analysis methods have been put forward as an excellent candidate to perform sustainability assessment recently, and a variety of applications have emerged [40]. MCA is formal approach that takes into account multiple criteria in order to help making decisions that matter [41]. MCA stands in contrast to single goal optimization and approaches which, when using "unifying units," may offset poor performance of one criterion by good performances of another criterion, therefore allowing for substitution and compensability between criteria [42].

MCA methods require data to be normalized in order to obtain comparable scales. A common method is the ratio normalization that attributes value 1 to the best performance on a criterion and a proportional value to the other performances [43]. The objective of this method is to provide an easy to use screening tool for assessment and comparison in the design phase, in order to point out key aspects that need to be improved on or further explored. In some cases, we have amended this method in a way that the most preferred performance was valued 1 while detrimental performance was valued 0 and, if applicable, the third value normalized in between. In some cases we were reduced to qualitative evaluation, assigning 1 for best, 0 for worst, and 0.5 for medium values.

Table 8 lists the normalized values of selected indicators. Routes B and C use one-third of raw materials from oil refinery products, and $50 \%$ of raw materials in Route A are renewable. Values are normalized accordingly. In terms of energy demand, Route B releases $746.3 \mathrm{MJ}$ energy, while reaction Routes $\mathrm{A}$ and $\mathrm{C}$ consume energy. We assigned Route A (1152.2 MJ/DMC production) a 0 value, to route B the value 1 , and normalized the consumption of Route $\mathrm{C}$ $(131.52 \mathrm{MJ} / \mathrm{DMC})$ to the value 0.54 . Only Routes $\mathrm{A}$ and $\mathrm{B}$ are $\mathrm{CO}_{2}$-based. Route $\mathrm{C}$ has therefore no direct $\mathrm{CO}_{2}$ implication. Route $\mathrm{B}$ consumes $\mathrm{CO}_{2}$, while Route A generates it. We assigned Route $B$ the value of 1 and Route $C$ value 0 and normalized Route $\mathrm{A}$ in between. In case of wastes, Routes $\mathrm{B}$ and $\mathrm{C}$ produce no wastes, while Route A produces low 
TABle 3: Process description for Route A.

\begin{tabular}{lccc}
\hline Process unit & Type & Conditions & Notes \\
\hline Reac & Stoichiometric reactor & $T=50^{\circ} \mathrm{C}, P=150$ bar & Conversion of $\mathrm{CH}_{3} \mathrm{OH}=8.3 \%$ \\
Sep & Component separator & Split fraction of $\mathrm{CO}_{2}=100 \%$ & Separation of unreacted $\mathrm{CO}_{2}$ \\
Flash & Flash separator & $T=97^{\circ} \mathrm{C}, P=3 \mathrm{bar}$ & Separation of methanol \\
Col 1 & RadFrac column & 15 stages, distillate rate $=1.421$, reflux ratio $=5$ & Concentration of DMC after distillation $=85.5 \%$ \\
Col 2 & RadFrac column & 15 stages, distillate rate $=0.07$, reflux ratio $=9$ & Cooling of DMC \\
Cond & Cooler & $T=20^{\circ} \mathrm{C}, P=1$ bar & \\
\hline
\end{tabular}

TABle 4: Process description for Route B.

\begin{tabular}{lccc}
\hline Process unit & Type & Conditions & Notes \\
\hline Reac 1 & Stoichiometric reactor & $T=100^{\circ} \mathrm{C}, P=140$ bar & Conversion of propylene oxide $=100 \%$ \\
Reac 2 & Stoichiometric reactor & $T=150^{\circ} \mathrm{C}, P=1 \mathrm{bar}$ & Conversion of methanol $=5.25 \%$ \\
Col 1 & RadFrac column & 15 stages, distillate rate $=2$, reflux ratio $=5$ & Separation of propylene carbonate \\
Col 2 & RadFrac column & 15 stages, distillate rate $=1.895$, reflux ratio $=5$ & Separation of methanol \\
Col 3 & RadFrac column & 15 stages, distillate rate $=0.06$, reflux ratio $=5$ & Concentration of DMC after distillation $=85.9 \%$ \\
Cond & Cooler & $T=20^{\circ} \mathrm{C}, P=1$ bar & Cooling of DMC \\
\hline
\end{tabular}

TABle 5: Process description for Route C.

\begin{tabular}{lccc}
\hline Process unit & Type & Conditions & Notes \\
\hline Reac & Stoichiometric reactor & $T=120^{\circ} \mathrm{C}, P=27$ bar & Conversion of $\mathrm{CH}_{3} \mathrm{OH}=16.49 \%$ \\
Sep & Component separator & Split fraction of $\mathrm{CO}$ and $\mathrm{O}_{2}=100 \%$ & Separation of unreacted $\mathrm{CO}_{\text {and } \mathrm{O}_{2}}$ \\
Flash & Flash separator & $T=99.1^{\circ} \mathrm{C}, P=3 \mathrm{bar}$ & Separation of methanol \\
Col 1 & RadFrac column & 15 stages, distillate rate $=1.307$, reflux ratio $=5$ & Concentration of DMC after distillation $=85.4 \%$ \\
Col 2 & RadFrac column & 15 stages, distillate rate $=0.148$, reflux ratio $=10$ & Cooling of DMC \\
Cond & Cooler & $T=20^{\circ} \mathrm{C}, P=1$ bar & \\
\hline
\end{tabular}

amounts of methyl formate. Therefore, $\mathrm{A}$ is valued 0 while $\mathrm{B}$ and $\mathrm{C}$ are valued 1 .

The yield in reaction Route $\mathrm{C}$ is the highest (1), as expected from a commercial process. The yields of Routes $\mathrm{A}$ and $\mathrm{B}$ are moderate; normalized values are 0.48 and 0.41 . Both have the potential to enhance the selectivity and yield as well. The yield of DMC in the process Route A can be improved by circumventing the thermodynamic limitations. The water generated in the process can be chemically trapped as discussed by Eta et al. [44] and thus the equilibrium can be shifted in the forward direction for a higher yield of DMC. The feedstock costs of raw materials for Route $\mathrm{C}$ are highest, and therefore it is valued 0 ; for Route $A$ the costs are the lowest, thus valued 1 , and route B has a normalized value of 0.67. The real processing costs are difficult to assess for Routes $\mathrm{A}$ and $\mathrm{B}$, which are in the design phase; therefore, theoretical figures of operational costs were used. The assessment was based on the composite costs of feedstock and energy, divided by the amount of produced DMC. Based on this, Route $\mathrm{C}$ is the most expensive (0), Route A is the cheapest (1), and Route $\mathrm{B}$ is moderate and has normalized value 0.3 .

For process conditions, the process temperature and pressure were evaluated. Room temperature $\left(21^{\circ} \mathrm{C}\right)$ and atmospheric pressure (1 bar) were considered the safest, which would be valued 1 . We assigned 0 for highest temperature $150^{\circ} \mathrm{C}$ (Route $\mathrm{B}$ ) and the highest pressure 150 bar (Route $\mathrm{A}$ ) normalized the other values, $50^{\circ} \mathrm{C}$ in Route $\mathrm{A} 0.61$ and $120^{\circ} \mathrm{C}$ in Route C 0.07 and 140 bar in Route B 0,07 and 27 bar in Route $\mathrm{C} 0,92$. These values were multiplied for a composite value. Health and safety issues are most severe for reaction Route C (0) due to the use of CO, less severe for Route B (0.5) that is using organic solvents, and benign in the case of Route A (1). Innovation potential was valuated based on the volume of articles published on these production methods and the percentage of recent papers. Most articles were written on subject related to Route A but only $20 \%$ of the relevant were recent, indicating a receding interest. In case of Route $B$, the volume of publications is moderate, but $50 \%$ of the most relevant are recent, which indicates this is of rising scientific relevance. The innovation potential of Route $B$ was evaluated highest (value 1) and Route A was normalized to 0.8 , while Route $\mathrm{C}$ with the fewest volume and least recent publications was valued 0.1 .

The results of this comparative assessment are presented in Figure 3. Route B (red line) seems to be the most positive from environmental and social points of view; the only negative issue is the relatively highest safety risk in terms of process conditions, but it performs best in terms of low energy consumption and $\mathrm{CO}_{2}$ balance as it consumes $\mathrm{CO}_{2}$. Route A (blue line) seems to have some potential 
TABLE 6: Facts and assumptions regarding the three reaction routes.

\begin{tabular}{|c|c|c|c|}
\hline & $\begin{array}{l}\text { Route A: } \\
\text { direct synthesis from } \\
\text { carbon dioxide and } \\
\text { methanol }\end{array}$ & $\begin{array}{l}\text { Route B: } \\
\text { transesterification of methanol and } \\
\text { propylene carbonate }\end{array}$ & $\begin{array}{l}\text { Route C: } \\
\text { oxidative carbonylation of } \\
\text { methanol (ENiChem) }\end{array}$ \\
\hline $\begin{array}{l}\text { Reaction route } \\
\text { (stoichiometric feed } \\
{[\mathrm{kmol}] \text { ) }}\end{array}$ & $\begin{array}{l}\mathrm{CO}_{2}+2 \mathrm{CH}_{3} \mathrm{OH} \rightarrow \\
\left(\mathrm{CH}_{3} \mathrm{O}\right)_{2} \mathrm{CO}+\mathrm{H}_{2} \mathrm{O}\end{array}$ & $\begin{array}{l}\mathrm{C}_{3} \mathrm{H}_{6} \mathrm{O}+\mathrm{CO}_{2} \rightarrow \mathrm{C}_{4} \mathrm{H}_{6} \mathrm{O}_{3} \\
\mathrm{C}_{4} \mathrm{H}_{6} \mathrm{O}_{3}+2 \mathrm{CH}_{3} \mathrm{OH} \rightarrow \\
\left(\mathrm{CH}_{3} \mathrm{O}\right)_{2} \mathrm{CO}+\mathrm{C}_{3} \mathrm{H}_{8} \mathrm{O}_{2}\end{array}$ & $\begin{array}{l}2 \mathrm{CH}_{3} \mathrm{OH}+1 / 2 \mathrm{O}_{2}+\mathrm{CO} \rightarrow \\
\left(\mathrm{CH}_{3} \mathrm{O}\right)_{2} \mathrm{CO}+\mathrm{H}_{2} \mathrm{O}\end{array}$ \\
\hline $\begin{array}{l}\text { Atom economy [\%] } \\
\text { (theoretical) }\end{array}$ & 83.3 & 60.8 & 83.3 \\
\hline Raw materials & $\mathrm{CO}_{2}$ and $\mathrm{CH}_{3} \mathrm{OH}$ & $\begin{array}{l}\mathrm{CH}_{3} \mathrm{OH}, \mathrm{CO}_{2}, \mathrm{C}_{3} \mathrm{H}_{6} \mathrm{O}_{3} \\
\text { Intermediate: } \mathrm{C}_{4} \mathrm{H}_{6} \mathrm{O}_{3}\end{array}$ & $\mathrm{CH}_{3} \mathrm{OH}, \mathrm{O}_{2}$ and $\mathrm{CO}$ \\
\hline Supply chain & $\begin{array}{l}\mathrm{CH}_{3} \mathrm{OH} \text { from natural gas } \\
\mathrm{CO}_{2} \text { separated from flue } \\
\text { gas by absorption (MEA) }\end{array}$ & $\begin{array}{l}\mathrm{CH}_{3} \mathrm{OH} \text { from syngas } \\
\mathrm{CO}_{2} \text { separated from flue gas by } \\
\text { absorption (MEA) } \\
\text { Propylene oxide from } \mathrm{H}_{2} \mathrm{O}_{2} \text { and } \\
\text { propene }\end{array}$ & $\begin{array}{l}\mathrm{CH}_{3} \mathrm{OH} \text { from natural gas } \\
\mathrm{O}_{2} \text { from air (distillation) } \\
\mathrm{CO} \text { from natural gas }\end{array}$ \\
\hline $\begin{array}{l}\text { Solvents and auxiliary } \\
\text { chemicals }\end{array}$ & IL101 as a promoter & No solvents or auxiliary chemicals & $\begin{array}{l}\text { No solvents or auxiliary } \\
\text { chemicals }\end{array}$ \\
\hline Catalyst & CHT-HMS & $\begin{array}{l}\text { First step: ion exchange resin D201 } \\
\text { Second step: IL } 103\end{array}$ & $\mathrm{CuCl}_{2}$ \\
\hline $\begin{array}{l}\text { By-products and } \\
\text { coproducts }\end{array}$ & $\begin{array}{l}\mathrm{H}_{2} \mathrm{O} \\
\text { unreacted } \mathrm{CH}_{3} \mathrm{OH}\end{array}$ & $\begin{array}{l}\text { Propylene glycol, unreacted } \\
\mathrm{CH}_{3} \mathrm{OH} \text {, and propylene carbonate }\end{array}$ & $\begin{array}{l}\mathrm{H}_{2} \mathrm{O} \text {, unreacted } \mathrm{CH}_{3} \mathrm{OH}, \\
\mathrm{O}_{2}, \mathrm{CO} \text {, and } \mathrm{H}_{2} \mathrm{O}\end{array}$ \\
\hline Waste and emissions & $\begin{array}{l}\text { Methylformate, unreacted } \\
\mathrm{CO}_{2}\end{array}$ & No wastes & No wastes \\
\hline Process conditions & $\begin{array}{l}\text { Pressure } 150 \text { bar } \\
\text { Temp. } 50^{\circ} \mathrm{C} \\
\text { Supercritical } \mathrm{CO}_{2}\end{array}$ & $\begin{array}{ll}\text { First } & \text { Pressure } 140 \text { bar } \\
\text { step: } & \text { Temp. } 100^{\circ} \mathrm{C} \\
& \text { Supercritical } \mathrm{CO}_{2} \\
\text { Second } & \text { Pressure } 1.01325 \text { bar } \\
\text { step: } & \text { Temp. } 150^{\circ} \mathrm{C} \\
\end{array}$ & $\begin{array}{l}\text { Pressure } 27 \text { bar } \\
\text { Temp. } 120^{\circ} \mathrm{C}\end{array}$ \\
\hline $\begin{array}{l}\text { Health and safety } \\
\text { issues }\end{array}$ & $\begin{array}{l}\text { Methyl formate } \\
\text { (i) is extremely flammable } \\
\text { (ii) is harmful if swallowed } \\
\text { or inhaled } \\
\text { (iii) causes serious eye } \\
\text { irritation } \\
\text { (iv) may cause respiratory } \\
\text { irritation }\end{array}$ & $\begin{array}{l}\text { Propylene oxide } \\
\text { (i) is extremely flammable } \\
\text { (ii) is harmful if swallowed, inhaled, } \\
\text { or came in contact with skin } \\
\text { (iii) may cause respiratory irritation } \\
\text { (iv) may cause genetic defects and } \\
\text { cancer }\end{array}$ & $\begin{array}{l}\mathrm{CO} \text { is } \\
\text { (i) flammable } \\
\text { (ii) toxic for human } \\
\mathrm{CO} \text { and } \mathrm{O}_{2} \text { must be fed at a } \\
\text { carefully controlled rate to } \\
\text { avoid the risk of explosion }\end{array}$ \\
\hline Volume of articles & 542 & 129 & 76 \\
\hline $\begin{array}{l}\text { Percentage of recent } \\
\text { publications }\end{array}$ & $25 \%$ & $50 \%$ & $8 \%$ \\
\hline
\end{tabular}

toward economic and social sustainability; however, in terms of environmental sustainability, it has some shortcomings, such as high energy consumption and waste generation. The commercial process (green line) performs best in terms of yield, which is expected from a mature process; however, it has the worst social sustainability performance and it is also based on nonrenewable feedstock. Table 9 summarizes the benefits and challenges of the three routes.

In summation, it can be asserted that Route B has the best potential toward sustainability, although there is still much research needed to improve yield and conversion and thus reduce the amounts of wastes. In this case, use of a better catalyst would be further useful and add to sustainability positively. As its shape also indicates, Route A is very conflicting, as it has almost equal amounts of positive and negative factors. Many of the challenges are, however, difficult to overcome, such as the use of nonrenewable feedstock and yield stemming from low theoretical atom economy. In the commercial process (Route $\mathrm{C}$ ), the toxicity of the reactant and the high feedstock price and production cost are failings that may not be further improved.

\section{Conclusions}

In order to drive sustainability in the chemical industry, there is a need for a methodology capable of assessing the impact of new choices in products, processes, and operations at the design phase. Most sustainability assessment methods are meant to be tools of sustainability management on the corporate level. There are tools available to assess the 
TABLE 7: Simulation results and cost calculations of reaction routes.

\begin{tabular}{|c|c|c|c|}
\hline & Route A & Route B & Route C \\
\hline Conversion of $\mathrm{MeOH}[\%]$ & 9.16 & $\begin{array}{l}\text { (1) Step: } 100 \\
\text { (2) Step: } 10.5\end{array}$ & 17 \\
\hline Selectivity to DMC [\%] & 90.56 & $\begin{array}{l}\text { (1) Step } 100 \\
\text { (2) Step } 50\end{array}$ & 97 \\
\hline Yield [\%] & 5.99 & 5.15 & 12.64 \\
\hline Atom economy [\%] (Real) & 7.19 & 8.47 & 15.17 \\
\hline Amount of DMC $(\mathrm{kmol})$ & 0.06 & 0.051 & 0.126 \\
\hline $\begin{array}{l}\text { Concentration of DMC } \\
\text { (vol-\%) }\end{array}$ & 85.6 & 85.9 & 85.4 \\
\hline $\mathrm{CO}_{2}$ emissions $[\mathrm{kmol}]$ & 0.92 & 0 & - \\
\hline $\mathrm{CO}_{2}$ consumption $[\mathrm{kmol}]$ & 0.08 & 1.00 & - \\
\hline $\mathrm{CO}_{2}$ balance & 0.84 & 1 & 0 \\
\hline $\begin{array}{l}\text { Energy consumption } \\
\text { (specific) [MJ/DMC } \\
\text { produced] }\end{array}$ & 1152.8 & -746.3 & 131.5 \\
\hline $\begin{array}{l}\text { Energy consumption } \\
\text { (Aspen) }[\mathrm{MJ}]\end{array}$ & 69.17 & -38.06 & 16.57 \\
\hline \multirow{4}{*}{$\begin{array}{l}\text { Costs of feedstock } \\
(€ / \mathrm{kmol})\end{array}$} & $\mathrm{CO}_{2}: 24.8$ & $\mathrm{CH}_{3} \mathrm{OH}: 28.9$ & $\mathrm{CH}_{3} \mathrm{OH}: 28.9$ \\
\hline & \multirow[t]{2}{*}{$\mathrm{CH}_{3} \mathrm{OH}: 28.9$} & $\mathrm{CO}_{2}: 24.8$ & $\mathrm{O}_{2}: 13.4$ \\
\hline & & $\mathrm{C}_{3} \mathrm{H}_{6} \mathrm{O}: 72.6$ & CO: 199 \\
\hline & tot. 53.7 & tot. 126.3 & tot. 241.3 \\
\hline $\begin{array}{l}\text { Operational costs } \\
\text { (feedstock + process) [€] }\end{array}$ & $53.7+18.7=72.4$ & $126.3-10.3=116$ & $241.3+4.5=245.8$ \\
\hline $\begin{array}{l}\text { Operational costs } \\
\text { (feedstock + process)/DMC } \\
\text { produced } € / \mathrm{kmol}\end{array}$ & 1206.7 & 2274.5 & 1950.8 \\
\hline $\begin{array}{l}\text { Treatment cost/waste } \\
\text { disposal cost }\end{array}$ & $\begin{array}{l}\text { High disposal cost of } \\
\text { methylformate } \\
\text { Water can be discharged to } \\
\text { drain }\end{array}$ & By-product can be sold & $\begin{array}{l}\text { Water can be discharged to } \\
\text { drain }\end{array}$ \\
\hline
\end{tabular}

TABLE 8: Sustainability indicator values.

\begin{tabular}{lccc}
\hline & Route A & Route B & Route C \\
\hline Environmental indicators & & & \\
$\quad$ Feedstock renewability & 1 & 0.67 & 0.67 \\
Energy intensity & 0 & 1 & 0.54 \\
CO $_{2}$ balance & 0.84 & 1 & 0 \\
$\quad$ Wastes & 0 & 1 & 1 \\
Economic indicators & & & \\
$\quad$ Yield & 0.48 & 0.41 & 1 \\
$\quad$ Feedstock price & 1 & 0.67 & 0 \\
$\quad$ Process costs & 1 & 0.3 & 0 \\
Social indicators & & & \\
$\quad$ Process conditions & 0 & 0 & 0.06 \\
$\quad$ Chemicals safety & 1 & 0.5 & 0 \\
$\quad$ Innovation potential & 0.8 & 1 & 0.1 \\
\hline & 6.12 & 6.55 & 3.37 \\
\hline
\end{tabular}

environmental performance of products, such as Life Cycle Assessment; however they do not take into account economic and social implications. For the assessment tool presented in this paper, the principles of Green Chemistry were used as the basis of evaluation. The objective of Green Chemistry to promote safer chemistry is its strength in terms of driving sustainability, but it also has some limitations. It was meant to provide guidelines for design rather than being an assessment or a screening tool. Sustainability assessments are multicriteria based evaluations; therefore, we used multicriteria assessment (MCA) to perform the evaluation of the three DMC routes. Cross-referencing the Green Chemistry principles with established sustainability assessment and reporting methods (Global Reporting Initiative, AIChE, IChemE, and $\mathrm{REACH}$ ), this paper suggested a manageable list of factors considered necessary and sufficient to gain an overview of impacts toward sustainability.

The renewable nature of feedstock, energy intensity, $\mathrm{CO}_{2}$ balance, and waste generation were evaluated as environmental indicators. To assess economic performance, yield, price of feedstock, and process and production costs were selected. In terms of social sustainability, process conditions and chemicals safety were assessed, the latter using the guidelines of REACH. In addition, innovation and knowledge potential was assessed based on the volume and novelty of scientific publications recently published. It was argued that these 
TABLE 9: Summary of sustainability assessment, benefits, and challenges to sustainability.

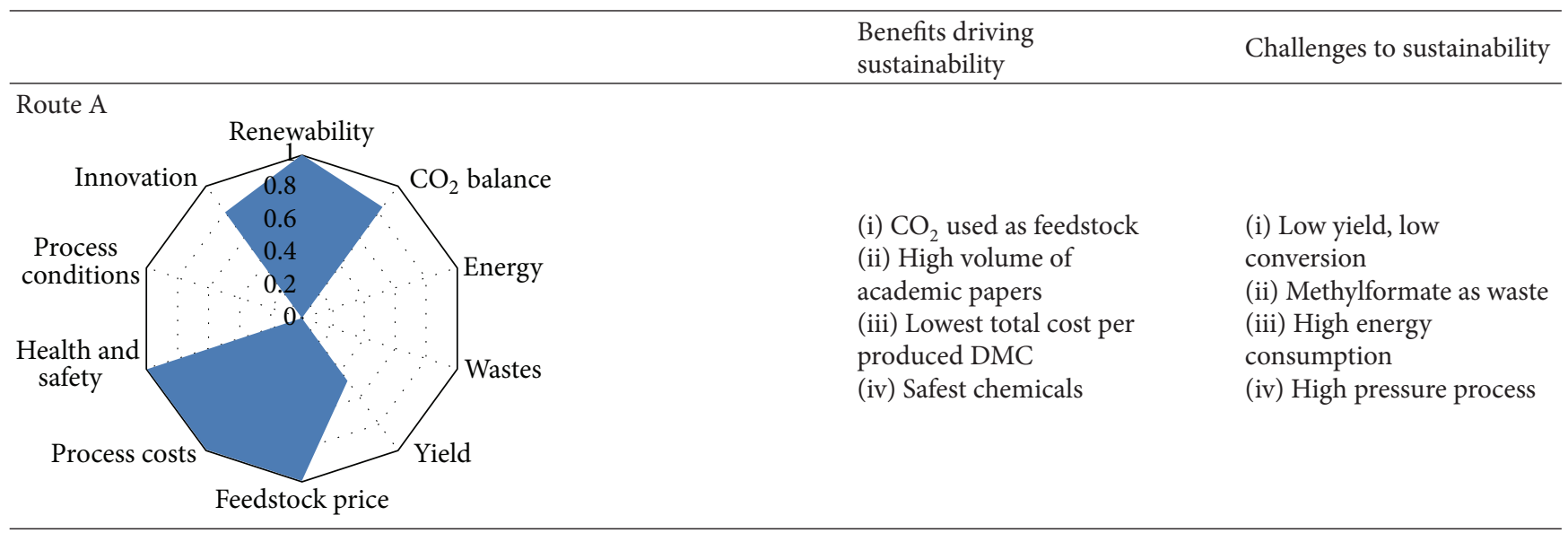

Route B

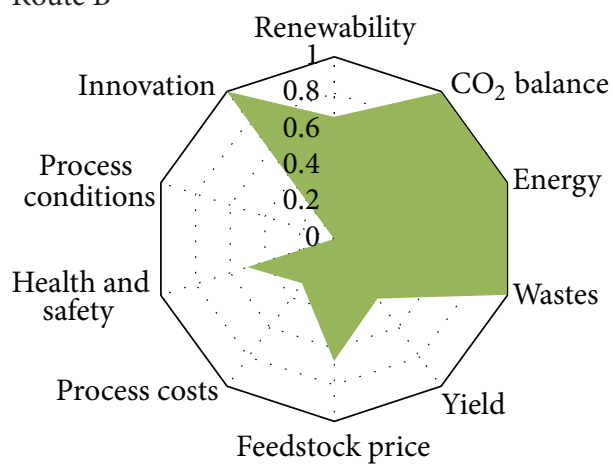

(i) $\mathrm{CO}_{2}$ is a feedstock in the first step

(ii) Valuable by-product

(iii) Energy win

(iv) Intensified academic research

(v) Consuming all $\mathrm{CO}_{2}$ (i) Oil refinery product used as feedstock

(ii) Low yield

(iii) Propylene oxide use is an inherent risk

(iv) Highest total cost per produced DMC

(v) High process temperature and pressure

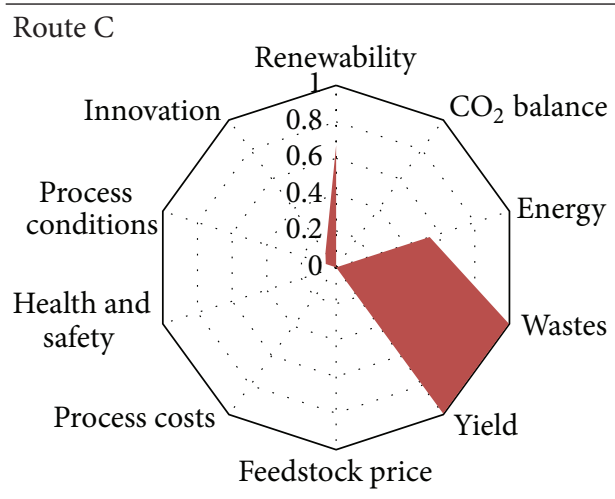

(i) Use of CO as reactant is an inherent risk

(i) Highest yield

(ii) No waste (ii) High feedstock and process costs (iii) High temperature process

(iv) Health and safety risks factors could be assessed based on reaction routes, laboratory scale experiments and results, as well as thermodynamic simulations. As MCA methods require data normalization, we used the common method of $0-1$ attribute values, 1 being the best and 0 the worst.

Of the three reaction routes to $\mathrm{DMC}$, two are $\mathrm{CO}_{2}$ based still in a research phase. The assessment indicated that transesterification has the best potential toward sustainability, although there is still much research needed to improve yield and selectivity. Direct synthesis from $\mathrm{CO}_{2}$ and methanol has many positive attributes, but an almost equal amount of negative factors. The commercial process, oxidative carbonylation, has performed worst in terms of sustainability, the toxicity of the reactant, and the high feedstock cost providing the major limitations to further improvement.

It can be concluded that the assessment allowed pointing out the main benefits of each reaction route, as well the major challenges to sustainability. This can further aid in orienting development efforts to key issues that need to be improved. Further, it can be asserted that, of the established sustainability tools our method builds on, Green Chemistry holds the most potential for chemical industry research and development. Green Chemistry is well known and trusted amongst chemical engineers and has practical tools and guidelines developed for process designers. Finally, it is suggested that multicriteria assessment can be used as a sustainability assessment method in the process design stage. 


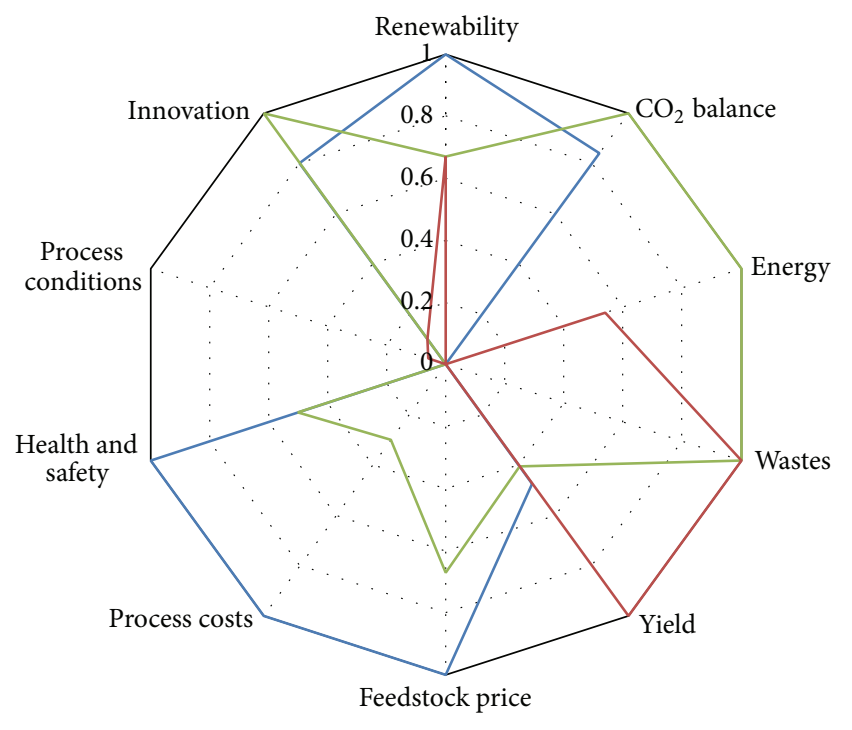

Route A
Route B
Route C

FIgURE 3: Comparison of the three DMC reaction routes.

\section{Abbreviations}

TBL: Triple bottom line

DMC: Dimethyl carbonate

GRI: Global Reporting Initiative

AIChE: American Institute of Chemical Engineers

IChemE: Institution of Chemical Engineers

REACH: The Registration, Evaluation, Authorization and Restriction of Chemicals

SDS: $\quad$ Safety data sheet

CSR: Chemical safety report

CSA: Chemical safety assessment.

\section{Conflict of Interests}

The authors declare that there is no conflict of interests regarding the publication of this paper.

\section{Authors' Contribution}

Satish Kabra and Esa Turpeinen contributed equally to this paper.

\section{Acknowledgments}

This work was performed within the collaborative project "Sustainable Catalytic Syntheses of Chemicals using Carbon Dioxide as Feedstock (GreenCatCO2)" supported by Department of Science and Technology, Government of India (DSTGOI), and The Academy of Finland. The authors would like to thank the Academy of Finland (Project nos. 129173 (SUSE) and 140122 (GreenCatCO2)) and the Finnish Funding
Agency for Technology and Innovation, Tekes (Project no. 40313/09 (Fermet)) for financial support. Ganapati D. Yadav also thanks DST for J.C. Bose National Fellowship and received support from R.T. Mody Distinguished Professor Endowment.

\section{References}

[1] WCED (World Commission on Environment and Development), "United Nations General Assembly document A/42/ 427," in Our Common Future, Oxford University Press, Oxford, UK, 1987.

[2] J. Elkington, Cannibals with Forks: The Triple Bottom Line of 21st Century Business, New Society Publishers, Stoney Creek, Conn, USA, 1998.

[3] T. Dyllick and K. Hockerts, "Beyond the business case for corporate sustainability," Business Strategy and the Environment, vol. 11, no. 2, pp. 130-141, 2002.

[4] J. B. Bowell, "Sustainability metrics, indicators, and indices for the process industries," in Sustainable Development in the Process Industries: Cases and Impact, J. Harmsen, Ed., pp. 5-23, John Wiley \& Sons, 2010.

[5] The GRI Sustainability Reporting Guidelines, 2013, https://www .globalreporting.org/resourcelibrary/GRIG4-Partl-ReportingPrinciples-and-Standard-Disclosures.pdf.

[6] J. García-Serna, L. Pérez-Barrigón, and M. J. Cocero, "New trends for design towards sustainability in chemical engineering: green engineering," Chemical Engineering Journal, vol. 133, no. 1-3, pp. 7-30, 2007.

[7] R. K. Singh, H. R. Murty, S. K. Gupta, and A. K. Dikshit, "An overview of sustainability assessment methodologies," Ecological Indicators, vol. 15, no. 1, pp. 281-299, 2012.

[8] M. Aresta and M. Galatola, "Life cycle analysis applied to the assessment of the environmental impact of alternative synthetic processes. The dimethylcarbonate case: part 1," Journal of Cleaner Production, vol. 7, no. 3, pp. 181-193, 1999.

[9] Directive 2011/92/EU of the European parliament and of the council of 13 December 2011 on the assessment of the effects of certain public and private projects on the environment, http://eur-lex.europa.eu/LexUriServ/LexUriServ.do?uri=OJ:L: 2012:026:0001:01:EN:HTML.

[10] World Business Council for Sustainable Development (WBCSD), Signals of Change: Business Progress Toward Sustainable Development, World Business Council for Sustainable Development (WBCSD), Geneva, Switzerland, 1997.

[11] OECD-Organisation for Economic Co-operation and Development, "An Update of the OECD Composite Leading Indicators Short-Term Economic Statistics Division, Statistics Directorate/OECD," 2002, http://www.oecd.org.

[12] The (AIChE) Sustainability Index: The Factors in Detail, 2009, http://www.aiche.org/resources/publications/cep/2009/january/aiche-sustainability-index-factors-detail.

[13] D. Tanzil, G. Ma, and B. R. Beloff, "Automating the sustainability metrics approach," in Proceedings of the AIChE Spring Meeting, New Orleans, La, USA, April 2004.

[14] M. Wilkinson, "Sustainable development and IChemE," Process Safety and Environmental Protection, vol. 78, no. 4, p. 236, 2000.

[15] IChemE sustainability metrics, sustainable development progress metrics recommended for use in the process industries, 2001, http://nbis.org/nbisresources/metrics/triple_bottom_line_ indicators_process_industries.pdf. 
[16] P. T. Anastas and J. C. Warner, Green Chemistry: Theory and Practice, Oxford University Press, New York, NY, USA, 1998.

[17] P. T. Anastas and M. M. Kirchhoff, "Origins, current status, and future challenges of green chemistry," Accounts of Chemical Research, vol. 35, no. 9, pp. 686-694, 2002.

[18] J. B. Manley, P. T. Anastas, and B. W. Cue Jr., "Frontiers in Green Chemistry: meeting the grand challenges for sustainability in R\&D and manufacturing," Journal of Cleaner Production, vol. 16, no. 6, pp. 743-750, 2008.

[19] W. Lilienblum, W. Dekant, H. Foth et al., "Alternative methods to safety studies in experimental animals: role in the risk assessment of chemicals under the new European Chemicals Legislation (REACH)," Archives of Toxicology, vol. 82, no. 4, pp. 211-236, 2008.

[20] Regulation (EC) No 1272/2008 of the European parliament and of the council of 16 December 2008 on classification, labelling and packaging of substances and mixtures, amending and repealing Directives 67/548/EEC and 1999/45/EC, and amending Regulation (EC) No 1907/2006, http://eur-lex.europa .eu/LexUriServ/LexUriServ.do?uri=OJ:L:2008:353:0001:01:EN: HTML.

[21] Regulation of the European parliament and of the council on classification, labelling and packaging of substances and mixtures, amending and repealing directives 67/548/EEC and 1999/45/EC, and amending regulation (EC) No 1907/2006, http://echa.europa.eu/fi/addressing-chemicals-of-concern/harmonised-classification-and-labelling/annex-vi-to-clp.

[22] C\&L Inventory database, 2014, http://echa.europa.eu/fi/information-on-chemicals/cl-inventory-database;jsessionid=F950E8759BC3897F24C962972266BCD9.livel.

[23] D. Delledonne, F. Rivetti, and U. Romano, "Developments in the production and application of dimethylcarbonate," Applied Catalysis A: General, vol. 221, no. 1-2, pp. 241-251, 2001.

[24] H. M. Wang, H. Wang, N. Zhao, W. Wei, and Y. Sun, "Highyield synthesis of dimethyl carbonate from urea and methanol using a catalytic distillation process," Industrial and Engineering Chemistry Research, vol. 46, no. 9, pp. 2683-2687, 2007.

[25] M. A. Pacheco and C. L. Marshall, "Review of dimethyl carbonate (DMC) manufacture and its characteristics as a fuel additive," Energy \& Fuels, vol. 11, no. 1, pp. 2-29, 1997.

[26] F. Rivetti, U. Romano, and D. Delledone, "Dimethyl carbonate and its production technology," in Green Chemistry, P. T. Anastas and T. C. Williamson, Eds., vol. 626 of ACS Symposium Series, pp. 70-80, 1996.

[27] Y. Katrib, G. Deiber, P. Mirabel et al., "Atmospheric loss processes of dimethyl and diethyl carbonate," Journal of Atmospheric Chemistry, vol. 43, no. 3, pp. 151-174, 2002.

[28] Y. Yu, X. Liu, W. Zhang et al., "Electrosynthesis of dimethyl carbonate from methanol and carbon monoxide under mild conditions," Industrial and Engineering Chemistry Research, vol. 52, no. 21, pp. 6901-6907, 2013.

[29] M. Wang, N. Zhao, W. Wei, and Y. Sun, "Synthesis of dimethyl carbonate from urea and methanol over $\mathrm{ZnO}$," Industrial and Engineering Chemistry Research, vol. 44, no. 19, pp. 7596-7599, 2005.

[30] W. Zhao, F. Wang, W. Peng et al., "Synthesis of dimethyl carbonate from methyl carbamate and methanol with zinc compounds as catalysts," Industrial and Engineering Chemistry Research, vol. 47, no. 16, pp. 5913-5917, 2008.

[31] P. Unnikrishnan and D. Srinivas, "Calcined, rare earth modified hydrotalcite as a solid, reusable catalyst for dimethyl carbonate synthesis," Industrial and Engineering Chemistry Research, vol. 51, no. 18, pp. 6356-6363, 2012.

[32] E. Pongrácz, E. Turpeinen, R. Raudaskoski, D. BallivetTkatchenko, and R. L. Keiski, " $\mathrm{CO}_{2}$ : from waste to resource for methanol-based processes," Proceedings of Institution of Civil Engineers: Waste and Resource Management, vol. 162, no. 4, pp. 215-220, 2009.

[33] F. Cavani, G. Centi, S. Perathoner, and F. Trifiro, Sustainable Industrial Process, Wiley-VCH, New York, NY, USA, 2009.

[34] D. Ballivet-Tkatchenko and S. Sorokina, "Open chain organic carbonates," in Carbon Dioxide Recovery and Utilization, M. Aresta, Ed., pp. 261-277, Kluwer Academic Publishers, Dordrecht, The Netherlands, 2003.

[35] S. K. Kabra, E. Turpeinen, G. D. Yadav, and R. Keiski, “Direct synthesis of dimethyl carbonate from methanol and carbon dioxide: a thermodynamic and experimental study," The Journal of Supercritical Fluids. To be submitted.

[36] P. Adhuri and G. D. Yadav, Insight into catalytic green chemistry and technology of industrial relevance [M.S. thesis], University of Mumbai, 2007.

[37] H. Kawanami, A. Sasaki, K. Matsui, and Y. Ikushima, "A rapid and effective synthesis of propylene carbonate using a supercritical $\mathrm{CO}_{2}$-ionic liquid system," Chemical Communications, vol. 9, no. 7, pp. 896-897, 2003.

[38] M. Nicola Di, C. Fusi, F. Rivetti, and G. Sasselli, "Patent: process for producing dimethyl carbonate,” Tech. Rep. EP 0460732, EniChem Synthesis S.p.A., 1991.

[39] Y. Du, F. Cai, D.-L. Kong, and L.-N. He, "Organic solventfree process for the synthesis of propylene carbonate from supercritical carbon dioxide and propylene oxide catalyzed by insoluble ion exchange resins," Green Chemistry, vol. 7, no. 7, pp. 518-523, 2005.

[40] M. Cinelli, S. R. Coles, and K. Kirwan, "Analysis of the potentials of multi criteria decision analysis methods to conduct sustainability assessment," Ecological Indicators, vol. 46, pp. 138148, 2014.

[41] V. Belton and T. J. Stewart, Multiple Criterial Decision Analysis. An Integrated Approach, Kluwer Academic, Boston, Mass, USA, 2002.

[42] T. Buchholz, E. Rametsteiner, T. A. Volk, and V. A. Luzadis, "Multi Criteria Analysis for bioenergy systems assessments," Energy Policy, vol. 37, no. 2, pp. 484-495, 2009.

[43] L. C. Dias and A. R. Domingues, "On multi-criteria sustainability assessment: spider-gram surface and dependence biases," Applied Energy, vol. 113, pp. 159-163, 2014.

[44] V. Eta, P. Mäki-Arvela, A.-R. Leino et al., "Synthesis of dimethyl carbonate from methanol and carbon dioxide: circumventing thermodynamic limitations," Industrial and Engineering Chemistry Research, vol. 49, no. 20, pp. 9609-9617, 2010. 

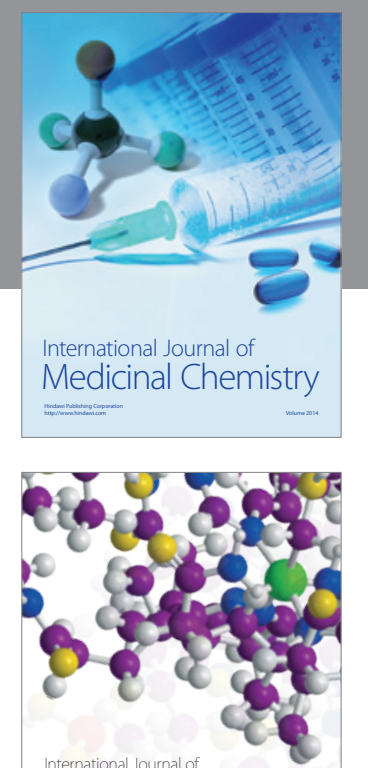

\section{Carbohydrate} Chemistry

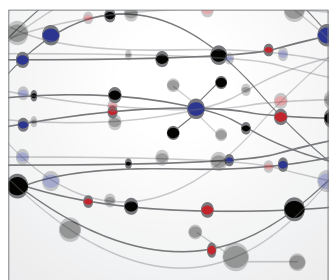

The Scientific World Journal
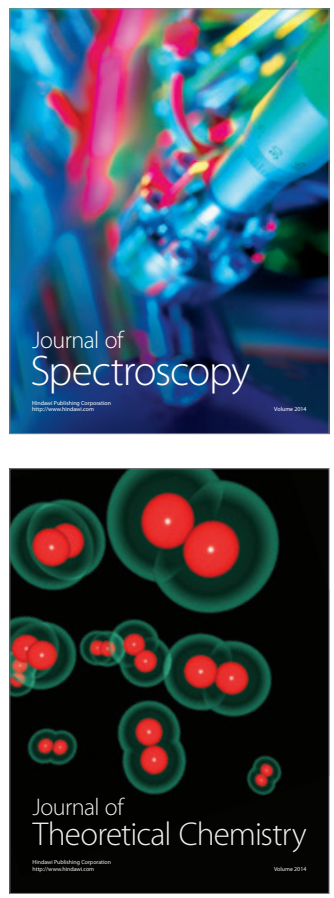
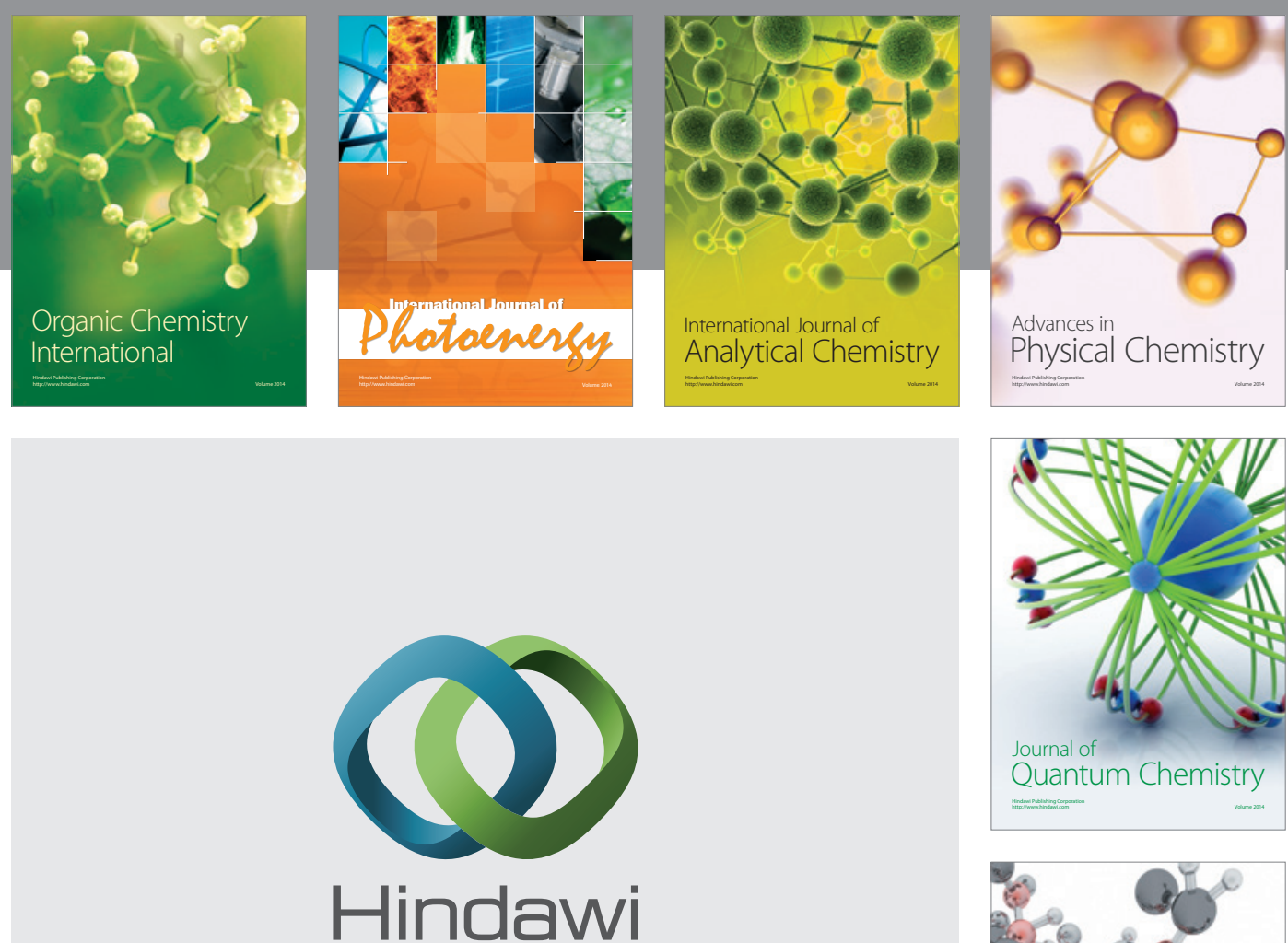

Submit your manuscripts at

http://www.hindawi.com

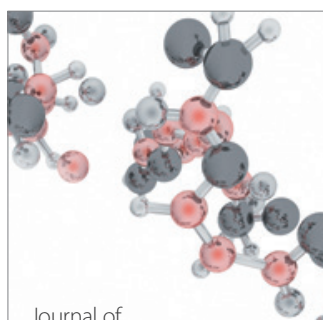

Analytical Methods

in Chemistry

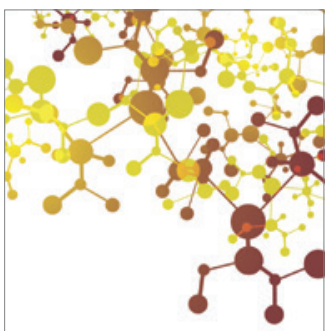

Journal of

Applied Chemistry

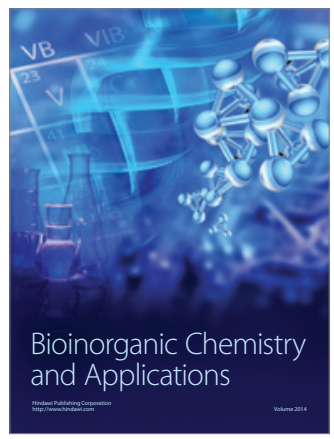

Inorganic Chemistry
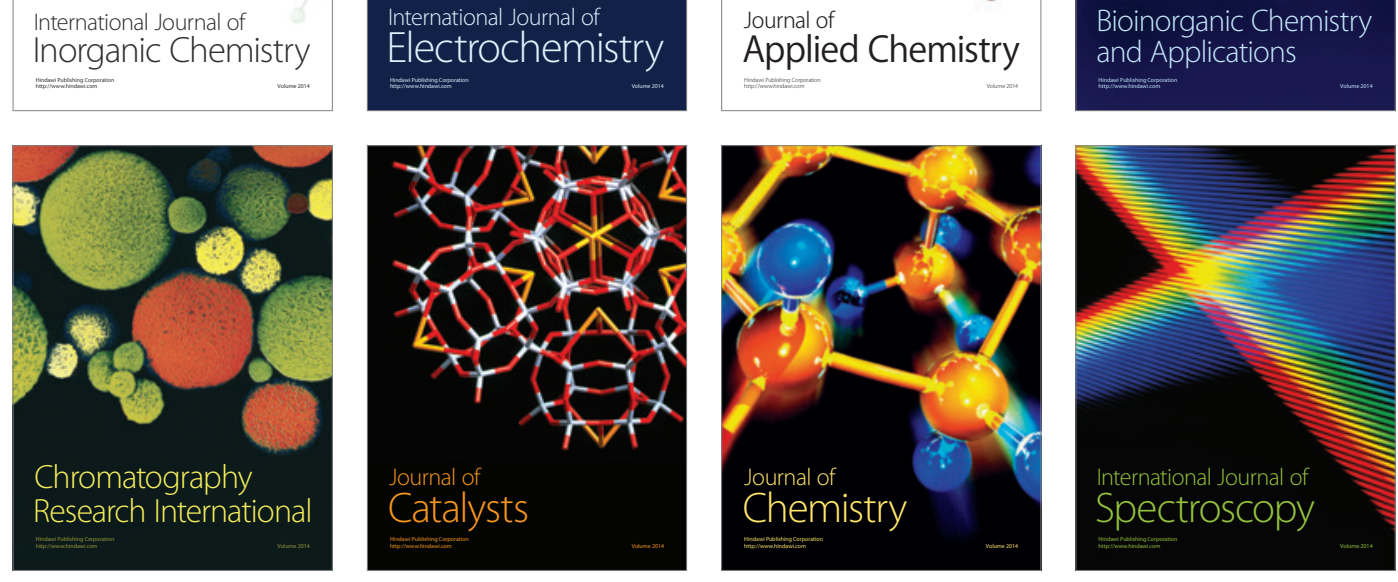